\title{
Dok. 3 \\ 17 września 2012 r. \\ Raport końcowy Grupy Refleksyjnej ds. Przyszłości Unii Europejskiej ministrów spraw zagranicznych Austrii, Belgii, Danii, Francji, Hiszpanii, Holandii, Luksemburga, Niemiec, Polski, Portugalii i Włoch
}

\section{WSTĘP I STRESZCZENIE}

Unia Europejska znalazła się w punkcie zwrotnym. Trwający kryzys zadłużenia publicznego i wciąż przyśpieszająca globalizacja stanowią bezprecedensowe, podwójne wyzwanie dla Europy. Jeśli chcemy, aby nasz kontynent miał przed sobą świetlaną przyszłość, i jeśli chcemy skutecznie promować nasze interesy i wartości w wielobiegunowym świecie, musimy ten kryzys ujarzmić.

Kryzys od dłuższego czasu ma dodatkowy wymiar polityczny. W wielu częściach Europy rośnie w siłę nacjonalizm i populizm, podczas gdy poczucie solidarności i przynależności europejskiej słabnie. Musimy podjąć działania mające na celu odbudowanie wiary w nasz wspólny projekt. Debatę polityczną na temat przyszłości projektu europejskiego należy przeprowadzić już dziś i musi ona objąć cały Kontynent. Co najważniejsze, muszą w nią być zaangażowani obywatele Europy.

Raport zawiera konkretne propozycje podejmujące wyzwania stojące przed Europa. Niektóre zaproponowane działania są krótkofalowe, inne mają dłuższą perspektywę czasową. Wiele $\mathrm{z}$ nich można wdrożyć korzystając $\mathrm{z}$ istniejących ram traktatowych; inne mogą wymagać zmian traktatów. Najważniejsze jest to, aby dobrać odpowiednią kolejność działań i zachować ich równowagę, łącząc elementy możliwe do wprowadzenia w życie w chwili obecnej z długoterminową wizją silniejszej Europy. Wzmocnienie UGW to rzecz jasna kluczowy aspekt naszych starań, mających na celu przezwyciężenie obecnego kryzysu.

Niniejszy raport jest wynikiem naszych osobistych przemyśleń. Pragniemy podkreślić, że nie wszyscy Ministrowie uczestniczący w jego sporządzeniu zgodzili się ze wszystkimi sugestiami przedstawionymi w trakcie naszych dyskusji. Należy także uwzględnić zobowiązania traktatowe $\mathrm{i}$ uprawnienia, które w zakresie niektórych polityk posiadają poszczególne państwa członkowskie UE. W skrócie, nasze sugestie są następujace:

I. Bezwzglednym priorytetem jest wzmocnienie Unii Gospodarczej i Walutowej.

Euro daje ogromne korzyści gospodarcze i jest najsilniejszym symbolem integracji europejskiej. Nasze propozycje stanowią konkretny wkład do reformy UGW zainicjowanej w trakcie czerwcowej Rady Europejskiej. Koncentrujemy się na inicjatywach możliwych do zrealizowania na bazie istniejących traktatów. Nie powinniśmy jednak wykluczać możliwości przeprowadzenia zmian traktatowych, jeśli zaszłaby taka konieczność. Naszym celem jest: 
- dalsze wzmocnienie rozszerzonych ram zarządzania gospodarczego, poprzez utworzenie unijnych mechanizmów, zarówno w celu nadzorowania zgodności budżetów państw członkowskich z zasadami unijnymi, jak i dalszego wspierania solidarności europejskiej;

- stworzenie bardziej wiążącej koordynacji polityk gospodarczych państw członkowskich $w$ dziedzinach kluczowych z punktu widzenia zrównoważonego wzrostu gospodarczej i zatrudnienia oraz niezbędnych dla zapewnienia stabilności strefy euro. Pomoże to przezwyciężyć istniejące dysproporcje oraz wzmocni szeroko pojętą konkurencyjność;

- ustanowienie, przy udziale Europejskiego Banku Centralnego, jednego i skutecznego mechanizmu nadzorczego obejmującego banki w strefie euro i w tych państwach członkowskich, które wyrażą chęć przyłączenia się do mechanizmu;

- zapewnienie pełnej legitymizacji oraz odpowiedzialności demokratycznej. Jeśli podejmowane są dodatkowe działania na poziomie europejskim i dotyczą one kompetencji UE, należy zaangażować Parlament Europejski w ramach procedury współdecydowania bądź konsultacji. Większość ministrów była zdania, iż w przypadku decyzji dotyczących wyłącznie strefy euro oraz państw „pre-in” chcących uczestniczyć w tym procesie już na obecnym etapie, należy rozważyć sposoby zaangażowania eurodeputowanych reprezentujących owe państwa, przy jednoczesnym pełnym poszanowaniu integralności Unii Europejskiej i Parlamentu Europejskiego. Jeśli dana decyzja dotyczy kompetencji narodowych, zwłaszcza budżetowych, wymagana jest zgoda parlamentów narodowych. Współpraca między Parlamentem Europejskim a parlamentami narodowymi powinna zostać dodatkowo wzmocniona poprzez stworzenie stałego komitetu wspólnego.

II. Wierzvmy, że po przezwycieżeniu krvzvsu w strefie euro, należy również poprawić szeroko pojete funkcionowanie Unii Europeiskiei. W szczególności UE musi podjąć zdecydowane działania mające na celu wzmocnienie pozycji Unii na świecie. Powinno to mieć miejsce niezależnie od reformy UGW i wykraczać poza jej zakres. Niektóre działania mogłyby zostać wdrożone na bazie istniejących traktatów - być może nawet w perspektywie krótkoterminowej - inne zaś mogłyby zostać podjęte jedynie $\mathrm{w}$ dalszej perspektywie poprzez zmiany traktatów.

- UE musi zwiększyć spójność i polityczne znaczenie swoich działań zewnętrznych. Wzywamy do przeprowadzenia znaczącej korekty decyzji dotyczącej Europejskiej Służby Działań Zewnętrznych (ESDZ) w 2013 r. Wysoki Przedstawiciel/Wiceprzewodniczący powinien odpowiadać za kluczowe dziedziny działań zewnętrznych. UE musi również zasadniczo wzmocnić Wspólną Politykę Bezpieczeństwa i Obrony oraz skuteczniej ksztaltować relacje z partnerami strategicznymi. W perspektywie długoterminowej powinniśmy dążý do zwiększenia liczby decyzji dot. WPBiO podejmowanych drogą większościową, tworzenia, w miare możliwości, wspólnych przedstawicielstw w ramach organizacji międzynarodowych oraz prowadzenia europejskiej polityki bezpieczeństwa. W opinii niektórych członków Grupy mogłoby to oznaczać powołanie wspólnej armii europejskiej.

- Proces wzmacniania poszczególnych polityk musi iść w parze z reformą instytucjonalną. Komisja powinna być silniejsza, tak aby mogła w pełni i skutecznie 
pełnić rolę motoru metody wspólnotowej. Jedną z możliwości jest stworzenie dedykowanych klastrów, w skład których wchodziliby komisarze dwóch szczebli (,junior" i „,senior”). Należy umożliwić Radzie ds. Ogólnych pełnienie roli koordynującej, o której mowa w Traktacie. Parlament Europejski powinien zadbać o większą demokratyczny wizerunek, któremu może się przysłużyć nominowanie przez każdą z frakcji czołowego europejskiego kandydata w nadchodzących wyborach do Europarlamentu.

- Patrząc realistycznie, w perspektywie długoterminowej reforma traktatowa w ramach Unii 28 lub więcej państw członkowskich będzie coraz trudniejsza. W opinii większości członków Grupy, zarówno przyjęcie, jak i wprowadzenie w życie poprawek do traktatów (z wyjątkiem rozszerzenia) mogłoby się odbywać za pomocą większości superkwalifikowanej państw członkowskich UE i ich mieszkańców. Poprawki obowiązywałyby te państwa członkowskie, które dokonały ich ratyfikacji.

- Ostatnim etapem długofalowego procesu powinien być sprawniejszy i skuteczniejszy system podziału władzy w Europie, cieszący się pełną legitymizacją demokratyczną. Niektórzy członkowie Grupy uważaja, że mogłoby to oznaczać bezpośredni wybór Przewodniczącego Komisji, który następnie osobiście wyznaczałby członków „Rządu Europejskiego”, a także Parlament Europejski posiadający inicjatywę ustawodawczą oraz drugą izbę dla państw członkowskich.

\section{PRZEZWYCIĘŻENIE OBECNEGO KRYZYSU DZIĘKI ZASADNICZEMU WZMOCNIENIU UNII GOSPODARCZEJ I WALUTOWEJ}

Kryzys zadłużenia publicznego w strefie euro już dawno stał się kryzysem zaufania do długoterminowej zdolności stabilizacji w poszczególnych państwach strefy euro.

Należy wspólnie promować zdrowe finanse publiczne, konkurencyjność, wzrost gospodarczy i zatrudnienie. Na poziomie europejskim powinniśmy zainicjować kolejny poziom rozwoju Jednolitego Rynku, jako jednego z naszych głównych atutów i najpotężniejszego motor wzrostu gospodarczego.

Powinniśmy zwiększyć wsparcie na rzecz MŚP, w tym poprzez łatwiejszy dostęp do funduszy unijnych i pobudzanie inwestycji, czego przykładem jest Europejski Pakt na rzecz Wzrostu Gospodarczego i Zatrudnienia. W tym zakresie należy również podjąc decyzje wzmacniające pozycję EBI. Należy także wspomóc tworzenie nowych miejsc pracy, koncentrując się zwłaszcza na kwestii bezrobocia wśród młodzieży.

Przezwyciężenie kryzysu wspólnej waluty w sposób zrównoważony będzie jednak możliwe tylko wówczas, gdy przezwyciężymy kryzys zaufania w strefie euro. Aby to osiągnąć, musimy zdecydowanie wzmocnić Unię Gospodarczą i Walutową.

Dogłębna reforma UGW oparta będzie na czterech etapach wyszczególnionych w raporcie przedstawionym na Radzie Europejskiej w czerwcu 2012 r. przez Przewodniczącego Rady Europejskiej, Przewodniczącego Komisji, Przewodniczącego Eurogrupy i Przewodniczącego Europejskiego Banku Centralnego. Musimy dążyć do ustanowienia zintegrowanych ram finansowych, zintegrowanych ram budżetowych, 
oraz zintegrowanych ram polityki gospodarczej, a także środków mających na celu zapewnienie legitymizacji demokratycznej i odpowiedzialności.

Skuteczna i stabilna Unia Gospodarcza i Walutowa ma centralne znaczenie dla funkcjonowania całej Unii Europejskiej. Jest to rzecz jasna kwestia niezwykłej wagi dla państw strefy euro, lecz dotyka ona także pozostałych państw członkowskich UE - także tych, które jak dotąd nie wprowadziły wspólnej waluty. W miarę możliwości należy zatem wdrażać reformy w ramach UE-27. Trzeba podjąć wszelkie działania reformujące w celu pogłębienie UGW. Nasze wysiłki koncentrujemy na inicjatywach możliwych do wprowadzenia na gruncie istniejących traktatów, lecz nie należy wykluczać możliwości przeprowadzenia zmian traktatowych, jeśli zaszłaby taka konieczność.

\section{Zintegrowane ramy budżetowe}

Na przestrzeni ostatnich dwóch lat podjęto ważne działania mające na celu usztywnienie ram dyscypliny budżetowej, zwłaszcza wewnątrz strefy euro. Musimy jak najszybciej dokończyć prace nad tzw. dwupakiem i bezzwłocznie wprowadzić w życie Pakt fiskalny. Lecz należy także sprawić, aby mechanizmy unijne były skuteczniejsze, tak aby wszystkie państwa członkowskie mogły przeciwdziałać niemożliwym do sfinansowania politykom fiskalnym i korygować je, a także przestrzegać przyjętych zasad w ramach narodowych procedur budżetowych. Wewnątrz Komisji należy wzmocnić rolę komisarza ds. gospodarczych i walutowych. Dążąc do zintegrowanych ram budżetowych, należy uwzględnić następujące elementy:

- skuteczna władza nadzorcza na poziomie europejskim, nadająca konkretne kompetencje nadzorcze instytucjom europejskim, umożliwiające nadzorowanie budżetów oraz procesu wdrażania polityk fiskalnych w państwach członkowskich, tak aby zapewnić, że państwa członkowskie wywiązują się z przyjętych zobowiązań w zakresie redukcji deficytu i zadłużenia. Należy przy tym w pełni uszanować odpowiedzialność państw członkowskich w kwestii opracowania budżetów narodowych;

- dodatkowe europejskie mechanizmy solidarnościowe; niektórzy członkowie Grupy proponują podjęcie działań mających na celu uwspólnotowienia ryzyka niewypłacalności z tytułu długu państwowego.

\section{Zintegrowane ramy polityki gospodarczej}

Musimy naprawić fundamentalną wadę UGW, jaką było stworzenie unii walutowej bez unii gospodarczej. Nie oznacza to, że wszystkie decyzje dotyczące polityki gospodarczej należy podejmować na poziomie europejskim. Tym niemniej, w kwestii kluczowych polityk gospodarczych mających istotne znaczenie dla zrównoważonego wzrostu gospodarczego i zatrudnienia, jak również dla stabilności strefy euro, potrzebne jest odpowiednie połączenie skutecznej, wiążącej koordynacji na poziomie europejskim oraz zdrowej konkurencji systemów narodowych i skuteczniejszych metod wymiany najlepszych praktyk. Dotyczy to zwłaszcza zasad funkcjonowania rynków pracy oraz stabilności systemów emerytalnych. Powinniśmy wykorzystać możliwości ist- 
niejące $w$ ramach traktatów, m.in. wzmocnioną współpracę. Ponadto, wielu członków Grupy jest zdania, ze dobrowolne na chwile obecną zobowiązania wynikające z postanowień paktu euro plus powinny mieć charakter wiążący. Rozwiązania te należałoby wdrożyć poprzez program partnerstwa gospodarczego pomiędzy państwami członkowskimi a szczeblem europejskim, wzorowany na programie przewidzianym w Traktacie o stabilności, koordynacji i zarządzaniu.

\section{Zintegrowane ramy finansowe}

Należy podjąć odważniejsze działania mające na celu poprawę funkcjonowania europejskich rynków finansowych. Dlatego opowiadamy się za utworzeniem jednego skutecznego mechanizmu nadzoru, w który zaangażowany będzie Europejski Bank Centralny. Mechanizm ten obejmowałby banki w strefie euro i te państwa członkowskie, które wyrażą zainteresowanie udziałem.

Niektórzy członkowie Grupy podkreślali wagę wspólnego systemu gwarancji depozytowych oraz europejskiego systemu restrukturyzacji i uporządkowanej likwidacji. W perspektywie średnioterminowej strefa euro musi umieć samodzielnie rozwiązywać potencjalne problemy wynikające z Unii Gospodarczej i Walutowej. Co za tym idzie, należy w dalszym ciągu dążyć do przekształcenia europejskiego mechanizmu stabilności w „Europejski Fundusz Walutowy” wyposażony w odpowiednie kompetencje.

\section{Umacnianie demokratycznej legitymizacji oraz odpowiedzialności}

Zasadniczemu pogłębieniu Unii Gospodarczej i Walutowej musi towarzyszyć większa demokratyczna legitymizacja. Tworzenie nowych kompetencji lub ustanawianie ściślejszej koordynacji polityk międzynarodowych musi się odbywać pod pełną demokratyczną kontrolą.

- Potrzebne jest silne zaangażowanie Parlamentu Europejskiego w dalszy rozwój UWG zgodnie z metodą wspólnotową, zaś jej rolę należy umocnić. W sytuacji, gdy działania na szczeblu europejskim, podejmowane w ramach UE lub poprzez większą koordynację państw członkowskich, dotyczą kompetencji UE, Parlament Europejski musi być włączony w proces decyzyjny - poprzez procedurę współdecyzji lub konsultacji. Konsultacje z Parlamentem Europejskim powinny być przeprowadzane m.in. w ramach europejskiego semestru przed sformułowaniem fundamentalnych aspektów (np. rocznej analizy wzrostu gospodarczego) lub odnośnie konkretnych zaleceń niosących skutki dla UE lub całej strefy euro. Jeżeli na poziomie europejskim wprowadzimy bardziej wiążącą koordynację określonych elementów paktu euro plus, również w tej dziedzinie wskazane są konsultacje z Parlamentem Europejskim. Większość członków była zdania, że w przypadku decyzji dotyczących tylko strefy euro oraz innych państw ,pre-in” i zainteresowanych udziałem, należy znaleźć sposób na silniejsze zaangażowanie eurodeputowanych z tych krajów, przy pełnym poszanowaniu integralności Unii Europejskiej oraz Parlamentu Europejskiego. W razie wykorzystania funduszy $z$ ewentualnego budżetu centralnego (obejmującego również te kraje) na potrzeby wsparcia reform 
strukturalnych $w$ jednym $z$ przedmiotowych państw członkowskich, Parlament Europejski powinien - przy szczególnym zaangażowaniu eurodeputowanych z zainteresowanych państw - wyrazić swoją zgodę zgodnie z procedurami przewidzianymi w traktatach.

- W sytuacji, gdy dodatkowe działania na szczeblu europejskim dotyczą kompetencji krajowych (w szczególności budżetu), parlamenty krajowe muszą wyrazić swoją zgodę. Odpowiednia informacja powinna również zostać przekazana do Parlamentu Europejskiego.

- W dziedzinie polityki gospodarczej i fiskalnej, współpracy pomiędzy Parlamentem Europejskim a parlamentami krajowymi należy ponadto dać nowe podstawy poprzez utworzenie stałego komitetu wspólnego.

\section{ULATWIANIE DALSZEJ INTEGRACJI ORAZ STRUKTURA DEUGOFALOWEGO ZARZĄDZANIA UNIĄ EUROPEJSKĄ}

Po przezwyciężeniu kryzysu euro musimy się również zająć usprawnieniem ogólnego funkcjonowania Unii Europejskiej. W szczególności, UE musi podjąć zdecydowane działania, aby umocnić swą pozycję na arenie międzynarodowej. Cel ten należy realizować niezależnie od reformy UGW. Pewne działania można podjąć w oparciu o istniejące traktaty - być może już w perspektywie krótkoterminowej - do innych zaś będzie można przystąpić tylko w perspektywie długoterminowej poprzez zmiany traktatów uzgodnione w ramach Konwentu.

\section{a) Europa jako globalny gracz}

W warunkach globalnego współzawodnictwa z innymi gospodarkami, ideami i modelami społecznymi kraje Europy będą w stanie zachować swoje wartości i z powodzeniem realizować swe interesy tylko wówczas, gdy będą zjednoczone. Aby to osiągnąć, potrzebujemy kompleksowego i zintegrowanego podejścia do wszystkich aspektów pozycji UE na arenie międzynarodowej. Oprócz WPZiB oraz WPBiO podejście takie musi również obejmować m.in. kwestie dotyczące handlu i zewnętrznej polityki gospodarczej, pomocy rozwojowej, poszerzenia Unii i polityki sąsiedztwa, zarządzania przepływem migrantów, negocjacji klimatycznych oraz bezpieczeństwa energetycznego.

- Musimy zwiększyć spójność działań zewnętrznych UE. Aby wypracować kompleksowe i zintegrowane podejście do wszystkich aspektów pozycji UE na arenie międzynarodowej, Europejską Shużbę Działań Zewnętrznych trzeba wzmocnić w ramach przeglądu decyzji ws. ESDZ zaplanowanego na 2013 r. Wysoki Przedstawiciel/Wiceprzewodniczący (oraz ESDZ) powinien odpowiadać za kluczowe obszary działań zewnętrznych (np. politykę sąsiedztwa); ponadto należy zwiększyć ich rolę w zakresie współpracy rozwojowej. Jeśli chodzi o inne obszary, trzeba wzmocnić instytucjonalną zdolność tych organów do koordynowania różnych unijnych graczy. Kroki te są niezbędne zwłaszcza po to, aby umożliwić Wysokiemu Przedstawicielowi całkowite przejęcie roli koordynatora w ramach Komisji. Dodatkowo potrzebne są jasne zasady wspólpracy pomiędzy Wysokim Przedstawicielem/Wiceprzewodniczącym 
a innymi komisarzami w sferze działań zewnętrznych (np. w kontekście ewentualnej dwustopniowej hierarchii komisarzy). UE musi ponadto podejmować bardziej spójne działania na forum organizacji międzynarodowych, np. poprzez składanie oświadczeń w kwestiach dotyczących WPZiB w imieniu całej Unii.

- Należy wzmocnić Wspólną Politykę Bezpieczeństwa i Obrony. Nasza polityka obronna potrzebuje bardziej ambitnych celów, które będą wykraczać poza inicjatywę łączenia i udostęnniania zdolności wojskowych (pooling and sharing). Trzeba korzystać z możliwości, jakie daje nam Traktat lizboński, w szczególności w zakresie stałej współpracy strukturalnej.

- Musimy zwiększyć efektywność relacji z naszymi partnerami strategicznymi. Wysoki Przedstawiciel ma tutaj do odegrania wiodącą rolę, zaś wsparcia powinny jej udzielić państwa członkowskie.

- Musimy zoptymalizować proces wyznaczania priorytetów w dziedzinie stosunków zewnętrznych. Należy usprawnić tryb pracy Rady do Spraw Zagranicznych. Opierając się na półrocznym cyklu planowania agendy, musimy nadać naszym konsultacjom bardziej strategiczny i celowy charakter. Potrzebujemy więcej nieformalnych spotkań w formule Gymnich i lepszej interakcji z Radą Europejską. Jedno spotkanie w roku, z udziałem ministrów spraw zagranicznych, należy poświęcić strategii stosunków zewnętrznych. Powinniśmy się zastanowić nad przeglądem Europejskiej Strategii Bezpieczeństwa.

Aby UE mogła na arenie międzynarodowej odgrywać rolę prawdziwego gracza, naszym zdaniem $w$ perspektywie dhugoterminowej powinniśmy:

- w dziedzinie WPZiB podejmować więcej decyzji na zasadzie większościowej lub przynajmniej uniemożliwić pojedynczemu państwu członkowskiemu blokowanie inicjatyw (a także dalej rozwijać koncepcję konstruktywnego wstrzymania się od głosu);

- tam gdzie to możliwe dążyć do wspólnej reprezentacji na forum organizacji międzynarodowych;

- zmierzać w kierunku Europejskiej Polityki Obrony obejmującej wspólne wysiłki w zakresie przemysłu obronnego (chodzi np. o utworzenie wspólnego rynku projektów zbrojeniowych); zdaniem niektórych członków Grupy docelowo mogłoby to oznaczać utworzenie europejskiego wojska.

\section{b) Umacnianie innych obszarów polityki}

Jeżeli w nowym globalnym porządku Europa pragnie utrzymać swoją pozycję, będziemy potrzebowali integracji również w innych głównych obszarach polityki. Dlatego w dziedzinie sprawiedliwości i spraw wewnętrznych postulujemy, aby zapewnić lepszą ochronę zewnętrznych granic strefy Schengen (poprzez powołanie „Europejskiej Służby Granicznej”) lub też - w perspektywie średnioterminowej - stworzyć europejską wizę. Innym obszarem, w którym potrzebujemy „więcej Europy”, jest zrównoważona polityka energetyczna: musimy zbudować działający wewnętrzny rynek energii oparty na europejskiej infrastrukturze energetycznej, poprawić wydajność energetyczną i zdefiniować wspólne zewnętrzne relacje energetyczne. 


\section{c) Reformy instytucjonalne: zwiększanie efektywności UE oraz umacnianie jej demokratycznej legitymizacji}

Oprócz konkretnych aspektów reformy UGW, dodatkowe uprawnienia na szczeblu europejskim oraz ściślejsza koordynacja polityk krajowych wymagaja zwiększenia zdolności UE do podejmowania działań oraz silniejszej legitymizacji demokratycznej.

\section{Zwiększenie zdolności do podejmowania działań}

- Komisję należy wzmocnić tak, by mogła efektywnie i w pełni odgrywać kluczową rolę motoru metody wspólnotowej. Trzeba usprawnić jej wewnętrzną organizację i procedury (jedna z możliwości przewiduje utworzenie określonych klastrów z dwustopniową hierarchią komisarzy); w perspektywie średniookresowej należy zająć się kwestią liczby komisarzy.

- Trzeba usprawnić współpracę z Radą, również po to, aby Rada Europejska była należycie przygotowywana przez różne konstelacje Rady, przede wszystkim Radę do Spraw Ogólnych, która powinna z kolei w pełni przejąc koordynującą rolę przewidzianą w Traktacie. Należy zwiększyć skuteczność konsultacji wewnętrznych w różnych składach Rady (np. poprzez zastosowanie połączonych interwencji). W perspektywie średnioterminowej powinniśmy powołać większą liczbę stałych przewodniczących i znaleźć równowagę pomiędzy stałymi i rotacyjnymi przewodnictwami (również w Radzie do Spraw Ogólnych) w celu zapewnienia większej efektywności różnym konstelacjom Rady. Być może warto również przeanalizować postulat lepszej koordynacji prac Rady i Komisji. Część ministrów wystapiła z propozycją powoływania jednej osoby na stanowisko przewodniczącego Komisji i przewodniczącego Rady Europejskiej.

- Zwiększeniu skuteczności europejskich decyzji może ponadto dopomóc częstsze stosowanie zróżnicowanej integracji, która - choć przewiduja ją traktaty - do tej pory praktycznie nie była wykorzystywana. Aby zwiększyć zdolność Unii do podejmowania działań, w perspektywie średniookresowej powinniśmy poszerzyć zakres decyzji podejmowanych kwalifikowaną większością głosów.

\section{Zwiększenie legitymizacji demokratycznej}

- Należy stale zwiększać demokratyczny wizerunek Parlamentu Europejskiego. Krokiem na tej drodze mogłoby być np. nominowanie przez każde europejskie ugrupowanie polityczne podczas kolejnych wyborów do PE głównego europejskiego kandydata, który ubiegałby się jednocześnie o stanowisko przewodniczącego Komisji. Ponadto potrzebujemy większego rozróżnienia pomiędzy większością i mniejszością w Parlamencie Europejskim, a także organizacji wyborów do Parlamentu Europejskiego tego samego dnia we wszystkich państwach członkowskich, stworzenia (ograniczonej) europejskiej listy w wyborach, czy też bardziej przejrzystej procedury powoływania przewodniczącego KE w Parlamencie Europejskim. Europejskie partie polityczne powinny działać na rzecz autentycznie „europejskiej przestrzeni politycznej”, która przyciągałaby uwagę europejskich obywateli do kluczowych zagadnień politycznych dotyczących ich wspólnej przyszłości. 
- Narodowe parlamenty powinny silniej angażować się w prace Unii Europejskiej zgodnie $\mathrm{z}$ duchem Traktatu $\mathrm{z}$ Lizbony. W tym celu należy zintensyfikować kontakty między PE oraz narodowymi organami ustawodawczymi. Mogą w tym dopomóc np. regularne spotkania, obecność eurodeputowanych podczas strategicznych debat dotyczących UE w parlamentach krajowych, wzmocnienie struktury COSAC oraz ogólnoeuropejskich sieci komisji parlamentów krajowych zajmujących się tym samym europejskim dossier. Głównym zadaniem krajowych organów ustawodawczych pozostanie jednak kontrolowanie poczynań rządów.

\section{d) Umacnianie Unii Europejskiej jako wspólnoty wartości}

- Trzeba zapewnić większe poszanowania fundamentalnych wartości zapisanych w art. 2 TUE. W tym celu należy wprowadzić nowy, prosty mechanizm, który w razie stwierdzenia naruszeń wartości wynikających z art. 2 TUE umożliwiałby Komisji sporządzenie raportu, wydanie zaleceń lub skierowanie sprawy do Rady. Mechanizm ten powinien być stosowany tylko w przypadku wyraźnego naruszenia przez państwo członkowskie fundamentalnych wartości lub zasad, np. zasady państwa prawnego.

\section{e) Usprawnienie ogólnego funkcjonowania Unii Europejskiej w perspektywie dhugoterminowej}

- Przeprowadzenie reformy traktatowej w UE liczącej 28 lub więcej państw członkowskich będzie niełatwym zadaniem. Większość członków Grupy jest zdania, że zarówno przyjęcie, jak i późniejsze wejście w życie zmian traktatów (z wyjątkiem poszerzenia Unii) powinno się odbywać poprzez superkwalifikowaną większość państw członkowskich i ich mieszkańców. Brak woli politycznej lub istotne opóźnienia w procesie ratyfikacji nie powinny dla dużej większości państw członkowskich stanowić przeszkody w dalszym pogłębianiu integracji. Dla wejścia w życie poprawek do traktatów europejskich należy ustanowić minimalny próg odpowiadający znaczącej większości państw członkowskich i ich obywateli. Zmiany te byłyby wiążące dla tych państw członkowskich, które dokonałyby ich ratyfikacji.

- Musimy wreszcie zastanowić się nad strukturami długofalowego zarządzania UE. Efektem długoterminowych prac nad tym zagadnieniem powinien być udoskonalony i skuteczny system podziału władz w Europie, który będzie posiadał pełną legitymizację demokratyczna. W opinii niektórych członków Grupy mógłby on obejmować następujące elementy: wybieranego w bezpośrednich wyborach przewodniczącego Komisji, który samodzielnie wyznaczałby członków swojego „europejskiego rządu”, Parlament Europejski z prawem inicjatywy ustawodawczej oraz drugą izbą dla państw członkowskich. 